\title{
Projekt InterTværs og interprofessionalitet som det innovative match
}

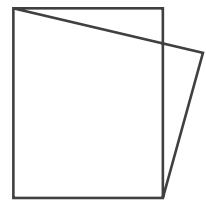

Cathrine Sand Nielsen, ph.d.stipendiat, VIA Sygeplejerskeuddannelsen og Københavns Universitet \& Tina Kramer, ph.d.stipendiat, Aarhus Universitetshospital og Københavns Universitet

\author{
Uddannelsesprojektet InterTværs er et \\ bud på fremtidens velfærdsuddannelser \\ og betragtes som et svar på omver- \\ denens krav om sammenhængende \\ patient-/borgerforløb. I projektet \\ forskydes den konventionelle mono- \\ faglighed til en interprofessionel og \\ tværsektoriel orientering mod samar- \\ bejde omkring patientforløb. I uddan- \\ nelsesmæssig forstand betyder det, at \\ projekt InterTværs' fokus på det klinisk- \\ praktiske samarbejde udfordrer såvel \\ det organisatoriske som pædagogiske \\ plan. Projekt InterTværs skal således \\ både fokusere på organisationsudvik- \\ ling og praktisk drift af studieforløbet \\ og på interprofessionel fag- og pædago- \\ gikudvikling. Projekt InterTværs følges \\ i to igangværende etnografiske studier \\ med fokus på henholdsvis involverede \\ studenter- og supervisionsteam.
}

\section{Baggrund}

Projekt InterTværs er siden 2012 fulgt med særlig interesse i at udforske de udfordringer og (interprofessionelle) håndteringer, som præger forløbet i henholdsvis de involverede studenter- og supervisionsteam. Feltarbejdets observationer og interviews med studerende og vejledere bekræfter forløbet som en innovativ læringskontekst, der er centreret om de interprofessionelle aktiviteter. Men feltarbejdet peger også på et kompliceret samspil og modspil fra involverede parter, der udfordrer projektets organisation. På denne baggrund blev det relevant at fokusere på de organisatoriske træk, der undervejs i feltarbejdet blev iagttaget og beskrevet som en 'indskudt arbejds- og læringsplatform'. Feltarbejdet viste, at Projekt InterTværs som udviklingsarbejde i sig selv fun- 
Projekt InterTværs og interprofessionalitet som det innovative match

\section{Når feltarbejdet følger denne InterTværs- platform, iagttages underviserpraksis- fællesskaberne og deres løbende videndeling og erfaringsudveksling på tværs af kliniksteder, professioner, organisationer og sektorer.}

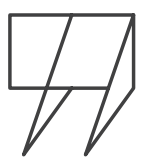

gerer som en platform, der skydes ind mellem sundhedsvæsen og uddannelsesinstitutioner. På platformen skabes underviser-praksisfællesskaber på tværs af uddannelser på campus og praksis, men også på tværs af kliniksteder fra forskellige professioner, organisationer og sektorer. Med den indskudte platform tilstræbes interprofessionel videndeling og erfaringsudveksling orienteret mod en fælles fag- og pædagogik udvikling. Men som artiklen viser, er det også på denne platform divergerende forventninger til og fortolkninger af projektet støder sammen og viser sig som eksempelvis et logistisk helvede og som sammenstød mellem professioner.

Når feltarbejdet følger denne InterTværs-platform, iagttages underviserpraksisfællesskaberne og deres løbende videndeling og erfaringsudveksling på tværs af kliniksteder, professioner, organisationer og sektorer. I så henseende følges den indskudte platform og den tilstræbte interprofessionelle fagudvikling i praktisk forstand som et udviklingsforløb. Metodologisk er princippet "Following-the-field" inspireret af Marcus (1996). Samtidig er princippet tilpasset projekt og aktører, således at InterTværs-forløbet følges “fra ø til $\varnothing "$ og som temporære skift mellem de involverede professioner, afdelinger og hjem. Dette 'ø-hopperi', som det kaldes i studierne, er af stor betydning for feltarbejdet og understreger feltarbejdets karakter af metodisk mangefold (Hammersley \& Atkinson 2007, Borgnakke 1996).

For os er hovedpointen, at studierne empirisk følger felt og projekt, dvs. følger InterTværs i fuld skala samt følger
InterTværs' praktiske kontekst og aktører gennem samlede forløb. Dette betyder for det første, at vore empiriske samlinger har en meget høj dækningsgrad. For det andet, at referencerne til de respektive politiske- og institutionelle niveauer og til InterTværs' styre-, arbejds- og sparringsgrupper er intakte. På den baggrund kan såvel InterTværs' missioner og visioner som konfrontation med praksis følges. Denne analysestrategiske konfrontation mellem den intenderede og faktiske praksis holder Projekt InterTværs fast på de ambitiøse interprofessionelle mål og forløb, men viser netop også de med- og modspillende faktorer i praktisk og i organisatorisk forstand. Med udgangspunkt i ovenstående er det relevant for denne artikel at fokusere på de organisatoriske træk og fremdrage de forventninger, med- og modspil, der 


\section{Her tager InterTværs del i det igangværende paradigmeskifte, der anskuer patient-/borger som aktiv og ligeværdig samarbejdspartner.}

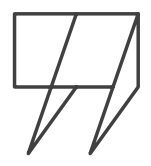

knytter sig til InterTværs platformen som interprofessionel arbejds- og læringsplatform.

\section{Missionen: At matche fremtidens krav}

På InterTværsPlatformen skabes underviser-praksisfællesskaber på tværs af ikke blot uddannelser på campus og praksis, men også på tværs af kliniksteder fra forskellige professioner, organisationer og sektorer. Med den indskudte platform tilstræbes interprofessionel fagudvikling som pædagogisk udvikling, der i udspringet var begrundet som et spørgsmål om at matche fremtidens krav. Som det blev understreget: "forudsætningerne for at sundhedspersonalets kompetencer fortsat matcher de krav der stilles i fremtiden er, at de sundhedsfaglige uddannelser indholdsmæssigt og organisatorisk tilrettelægges således, at de følger udviklingen i sundhedsvæsenet" (InterTværs Rapport, 2013, s. 5). Med fokus på 'at matche udviklingstendenser og kompetencekrav' blev InterTværs konstrueret i et samarbejde mellem aarhusianske chefer fra hospital, kommune, universitet og professionshøjskolen VIA. At InterTværs' mission formuleres på chefniveau betyder, at ideer til udviklingsprojekt og platforme i udspringet kommer ovenfra. Men det betyder også, at der blot er sat en ramme for initiativer, der dernæst skal komme nede fra. De initiativer, der skal komme nedefra, relateres til begrundelser for InterTværs som uddannelsesprojekt. Der skal udvikles interprofessionelle studieforløb som 'robuste modeller' til styrkelse af samarbejdskompetencer hos studerende (InterTværs Rapport 2013, s. 10) med det perspektiv, at de som kommende medarbejdere medvirker til at modernisere sundhedsvæsenet. Dette perspektiv understreger, at InterTværs søger at matche fremtidens krav ved at koncentrere udvikling af samarbejdskompetencer i den interprofessionelle satsning, projektet selv repræsenterer. Organisatorisk følges dette op ved, at InterTværs-forløbet tilrettelægges som et interprofessionelt team af studerende, der fortløbende samarbejder i et patient-/ borgerforløb. De studerende kommer fra hele det sundhedsfaglige spektrum, dvs. fra medicin-, sygepleje-, ergoterapeut-, fysioterapeut-, ernæring \& sundhedssamt bioanalytikeruddannelser. Med denne håndfaste version af interprofessionalitet står InterTværs-forløbet tydeligt i kontrast til traditionelle studieforløb, hvor studerende er i praktik på én afdeling eller ét lokalområde, og hvor de vejledes af professionelle fra egen profession. Den tilrettelagte interprofessionelle funktionsudøvelse er ligeledes håndfast: InterTværs-teamet gives første uge fælles ansvar for pleje og behandling relateret én patient på hospitalet. Dernæst i anden uge fælles ansvar for at følge en borger i kommunen.

I feltarbejderne følger vi måderne, hvorpå InterTværs søger at matche krav gennem ansvarsoverdragelser til de interprofessionelle team. Her iagttages, hvordan et begreb om 'Relationel koordinering' får betydning ved at betone, at ansvarsoverdragelsen rettes mod interprofessionelle arbejdsprocesser, der er præget af gensidig afhængighed, uforudsigelighed og tidspres.

\section{'Relationel koordinering'}

Med praktisk fokus på koordinering og kommunikation i samarbejde bliver 'Relationel koordinering' i InterTværs' udviklingsarbejde både et centralt begreb og 
Projekt InterTværs og interprofessionalitet som det innovative match

indarbejdet i den såkaldte InterTværs Model (InterTværs Model 2015, s. 8). Relationel koordinering er udviklet af Jody $\mathrm{H}$. Gittell og samlet fremlagt i Effektivitet i sundhedsvæsenet - samarbejde, fleksibilitet og kvalitet (Gittell 2012). Gittells karakteristik har reference til ledelse og organisering af kerneydelser i såvel den offentlige som private sektor. Med de udfoldede beskrivelser af arbejdsprocesser præget af gensidig afhængighed, uforudsigelighed og tidspres giver Gittell en karakteristik af de tidstypiske kendetegn for sundhedsvæsenet og dermed for InterTværs' kontekst. Relationel koordinering defineres af Gittell som: "en koordinering af arbejdsprocesser gennem relationer, der bygger på fælles mål, fælles viden og gensidig respekt" (Gittel 2012, s.37). Fokus er produktivitet, kvalitet og arbejdsglæde. Gittell identificerer syv egenskaber med betydning herfor: fælles mål, fælles viden, gensidig respekt, problemløsende samt hyppig, rettidig og korrekt kommunikation. Gittells organisatoriske perspektiv og forskningsambition er at bidrage til et ledelsessystem, som fremmer relationer mellem medarbejdere og sætter dem i stand til at koordinere (Gittell 2012). Netop på ledelsesniveauet viser vore analyser et klart interessesammenfald mellem Gittells og InterTværs' målsætninger. Analyserne viser, hvordan Gittels syv egenskaber undervejs i udviklingen af InterTværs-forløbene kommer til at fungere som pejlemærke for studenterteam og supervisorer.

Men om end der afspejles interessesammenfald, er der også markante forskydninger. Gittell fokuserer på organisation og ledelsesniveau. InterTværs derimod skærper opmærksomheden på uddannelsesniveauet og forskyder interessen til tværsektoriel- og patient-/borgerorien- tering. InterTværs valgte tidligt i forløbet betegnelsen 'Interprofessionel læring og samarbejde' (IPLS) og med inspiration fra CAIPE (2002) definerede dette som “studerende skal lære med, af og om hinanden for at styrke samarbejdet og kvaliteten i plejen og behandlingen" (InterTværs Rapport 2013, s. 9). Senere blev dette udvidet med en orientering imod fælles mål, som er patientens/borgerens mål" (InterTværs Model 2015, s. 6). For feltarbejdet og de empiriske analyser betyder disse interessesammenfald og forskydninger, at der i udspringet og på ledelsesniveauet kan identificeres projektnære træk og organisatoriske tiltag, hvor InterTværs søger både at matche fremtidens krav og Gittells perspektiver. Til gengæld viser analyserne på uddannelsesniveauet også, hvordan de selvsamme match og perspektiver brydes, eksempelvis af praktisk-organisatoriske vanskeligheder, der knytter sig til det logistiske helvede og til den vanskelige pendulering mellem de interprofessionelle kompetencer og monoprofessionelle baggrunde. Men vigtigst i denne artikels sammenhæng er det, at feltarbejdets analyser peger på, hvordan InterTværs netop på uddannelsesniveauet skal betragtes som en platform, hvor de involverede ledere, vejledere og studerende bliver primære aktører for udvikling af 'Relationel koordinering'. Når Relationel koordinering og IPLS inddrages i analyserne, repræsenterer de både en projektnær beskrivelse af opgaven, som InterTværsPlatformen skulle løse og en feltnær beskrivelse af de problemer og konflikter, der udspiller sig i den tilstræbte interprofessionelle fag- og pædagogikudvikling. Som det vil fremgå, er Relationel koordinering både platformens hensigt og problem.

\section{InterTværs som platformsudvikler} - den trojanske hest

Feltarbejdet viser, hvordan InterTværs som projekt mellem fire involverede organisationer udvikler en platform til håndtering og udvikling af interprofessionelle, patientorienterede studieforløb. På ledelsesniveauet viser analyserne, hvordan politiske krav om kvalificering af det sammenhængende patient-/ borgerforløb håndteres som en fælles udfordring mellem sundhedsvæsen og professionsuddannelser. Chefniveauet ansatte en projektleder til at udvikle projektet i samarbejde med en arbejdsgruppe bestående af kliniske- og teoretiske underviser-repræsentanter fra de fire organisationer. Indlejret i intentionen identificeres et ønske om, at diskursen spredes i feltet via uddannelsesprojektets aktører. Analyserne viser her, hvordan det overordnede chefled konfirmerer og legitimerer ideen. Feltarbejdets princip (followingthe-field) muliggør analyse af, hvordan InterTværs som uddannelsesniveauets projekt indskydes som en platform, hvor aktørerne gives tid, mål og midler til udviklingsarbejdet. Med InterTværsPlatformen sendes uddannelsesniveauets projekt på mission, hvor platformen og dens aktører som en trojansk hest skal fungere som katalysator for udvikling af sundhedsvæsenet. Hvis feltarbejdet har kunnet følge den trojanske hest, dvs. følge selve indskydningen af platformen, har feltarbejdet også iagttaget en markant forskydning. Undervejs forskydes platformens virksomhed nemlig mod klinikken, som det uddybes nedenfor.

\section{Forskydning mod klinikken} InterTværsPlatformen udfordrer professionsuddannelsernes traditionelle vekselvirkning mellem teori og praksis. 
Tema: Innovation og uddannelse

Feltarbejdet viser, hvordan InterTværs fastholder denne vekselvirkning gennem referencer til de studerendes uddannelses- og praktiksteder. Men feltarbejdet viser også, hvordan InterTværsPlatformen og dermed uddannelsesprojektet forskydes til et overvejende klinisk udviklingsprojekt. De praktiske markeringer af dette gives ved: projektlederens tilhørssted, mødernes afholdelse på hospitalet og hospitalets overrepræsentation i grupperne. Disse træk forstærkes, da styregruppen indlemmes i hospitalets uddannelsesråd. Men den stærkeste markering ligger nok i InterTværs egen mission, nemlig at udvikle en model for interprofessionel og patient-/borgerorienteret samarbejde, der overskrider såvel de eksisterende monoprofessionelle uddannelses - som praktikmoduler. InterTværs skulle så at sige fungere som et professions-praksisorienteret alternativ. Placeret i afslutningen af de studerendes uddannelsesforløb er også de studerende orienteret mod den professionelle praksis. Feltarbejdet har vist styrken af denne praksisorientering, men også omkostningerne forbundet hermed. Da uddannelsesudvikling foregår med InterTværs i det kliniske felt, er det udviklet uden uddannelsernes direkte indflydelse. I samtaler og interview med uddannelsesledere fra professionsuddannelserne gives udtryk for, at 'InterTværs ikke er vokset sammen med uddannelserne, men er vokset udenom'. Der berettes om, at "vi har skullet møve os ind" og har fået rollen som "spielverderber" (lyseslukker), der paradoksalt må sige, at "det kan ikke lade sig gøre" (FokusInt. U.leder, 2015). Det problematiseres videre, hvorvidt sundhedsvæsenets problemer med manglende sammenhæng i patient-/ borgerforløb kan løses ved, at "man prøver at proppe noget ind $\mathrm{i}$ uddannelser for at forandre praksis". I den uddannelsesmæssige praksis betyder det, at de involverede oplever en forskydning af InterTværs mod klinikken, der både i organisatorisk og i pædagogisk forstand betyder 'forskudt - væk fra hoveduddannelsen'.

\section{Forskudt mod politikken og aftagerperspektivet}

Forskydningen væk fra hoveduddannelsen kan være en utilsigtet virkning ved Projekt InterTværs, som forstærkes yderligere på det politiske niveau og af et stedse mere indflydelsesrigt aftagerperspektiv. Tendensen iagttages aktuelt i det igangværende revisionsarbejde med udvikling af ni sundhedsuddannelser. Branchens parter fra KL, Sundhedsstyrelsen, Sundhedskartellet, Danske Regioner og studerende involveres. De undervisnings-professionelle uddannelsesledere og teoretiske- og kliniske undervisere fremhæves dog ikke som parter, der skal involveres. Ifølge formand for Danske Professionshøjskoler var vigtigheden af alle parters deltagelse ellers understreget, som det fremgår af følgende udtalelse: "I dette arbejde er det vigtigt, at alle parter kommer $\mathrm{i}$ spil med den viden, vi hver især har. En forudsætning for det er, at vi ikke ser samarbejdet mellem regioner, kommuner og professionshøjskoler som et kunde/leverandørforhold, men at vi ser hinanden som ligeværdige partnere i den vigtige samfundsmæssige opgave, det er, at vores sundhedsvæsen fungerer og er forberedt på fremtidens opgaver" (Cit. Harald Mikkelsen, Sundhed 2016.dk). Den stærke understregning af fremtidens opgaver og behovet for, at sundhedsuddannelserne og professionshøjskolerne matcher opgaverne genkendes. InterTværs intentioner om interprofessio- nelle aktører, der lærer 'at lære af, med og om hinanden', genkendes og genfindes også. Men samtidig gives aftagerne - og ikke de undervisningsprofessionelle en central rolle, ligesom den politiske version af aftagerperspektivet kommer i fokus for uddannelsesudvikling. Denne politiserede rettethed mod den erhvervsog samfundsmæssige nytte, hvor også uddannelsesudviklingen begrundes direkte i samfundsmæssig nytte, synes aktuelt at forstærke InterTværs politiske legitimitet, men samtidig at svække projektets uddannelsespraktiske forankring og egne praksisfællesskaber. For InterTværs er denne udvikling et kritikpunkt og internt et tilbageslag, alt den stund at platformen ikke mindst blev skabt for at styrke uddannelsesprojektets egne (inter)professionelle praksisfællesskaber.

\section{InterTværsPlatformens 'egne' og nye praksisfællesskaber}

Feltarbejdet har vist, hvordan InterTværs skaber platforme for aktører på tværs af professioner, organisationer og sektorer - med mulighed for at mødes - netop på tværs. Aktørerne fra fem uddannelser, fire hospitalsafdelinger og ni lokalområder fordelt geografisk i kommunen repræsenterer InterTværs' egne praksisfællesskaber. Samtidig repræsenterer aktørerne egen profession, uddannelse eller klinik, og refererer til en hel organisation eller sektor. Hermed repræsenteres mange nuancer $\mathrm{i}$ forhandling om de Gittell-inspirerede syv egenskaber og fælles mål for InterTværs studieforløbet. I forhold hertil peger feltarbejdets empiriske analyser på mange nuancer og på gennemgående træk og mønstre. Der peges også på et næsten paradoksalt udsagn om det vigtige ved udnævnelse af fælles værdier og mål. Det vigtige synes at være a) at alle de involverede 


\section{... fremstår InterTværs som et udviklingsprojekt, der i praktisk forstand skaber et inter- professionelt uddannelsesalternativ.}

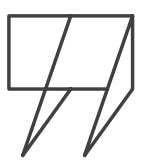

uddannelser skal kunne genfinde egen professionsforståelse og b) alle skal sætte det centrale i InterTværs, dvs. det patient-/borger centrerede, interprofessionelle og tværsektorielle som fælles mål. En næranalyse af bestræbelsen er endnu ikke foretaget, men foreløbigt fastholder vi hovedpointen. Som de involverede understreger det, er hovedpointen, at deltagelse i InterTværs forløbet har skabt nye underviserpraksisfællesskaber på tværs af professioner, organisationer og sektorer. I disse, projektets egne, praksisfællesskaber forhandles og skabes studieplaner, som ikke er funderet i én profession og én organisation, men interprofessionelt, patient-/borgercentreret og på tværs af sektorer.

Med den fælles praksis på tværs følger opbygning af underviser-fællesskaber, som inspireret af Lave og Wenger meningsfyldt kan benævnes underviserpraksisfællesskaber på tværs. I så fald betragtes praksisfællesskabet som deltagere i aktivitetssystemer, hvor deltagerne deler en fælles forståelse af, hvad de gør, og hvad det betyder for deres liv og for fællesskabet (Lave
\& Wenger 2004, s.233). I så fald følges også Wengers eftergående definition af det fælles videns-domæne (Wenger 2004, s. 285). I feltarbejdet er et fælles videns-domæne identificeret som et videns-domæne for interprofessionel uddannelse med anvendelse af begreber som 'fælles mål', 'facilitere på tværs' og 'interprofessionelle konferencer'. Begreberne høres i brug undervejs i forløbet, ligesom videns-domænet kan 'ses' vokse frem i takt med, at der skabes en fælles ramme for studieforløbene.

\section{Interprofessionel fag-} og kompetenceudvikling

I perioden 2013 til 2015 skaber InterTværs en model for et interprofessionelt studieforløb, gennemfører konkrete forløb, erfaringsopsamler disse samt videreudvikler modellen (InterTværs Rapport 2013, InterTværs Model 2015). Kliniske patient-/borgercentrerede, interprofessionelle, tværsektorielle studieforløb for studerende fra sundhedsuddannelser får hermed et konkret praktisk udtryk. Tilsvarende gælder spørgsmålene om interprofessionel fag- og kompetenceudvikling hos de involverede supervisorer.
For at udtrykke det med Dales klassiske kompetenceniveauer for professionel undervisning, så konstruerer, planlægger og reflekterer InterTværs et studieforløb på K2-niveau, gennemfører undervisningen på K1-niveau, samt legitimerer i forhold til didaktisk teori på K3-niveau (Dale 1989). I så henseende peger feltarbejdet på, at underviser-praksisfællesskaberne gennem viden- og erfaringsudveksling afspejler såvel K1-, K2-, K3-handlinger og refleksioner, men desuden afspejles, hvordan K1- og K2-handlinger er organisatoriske og praktiske udfordringer, der kun næsten kan håndteres. lkke mindst viser analyserne på det institutionelle niveau dét, feltet kalder "et logistisk helvede" med at få InterTværs uendeligt mange dele til at passe sammen. Her bliver det 'at skaffe' og 'afstemme inddragelse af' moduler, studerende, vejledere/undervisere og patientforløb et selvstændigt arbejdsområde. Det bliver tillige et eksempel på, at platformen er redskab til brug for praktisk udvikling og drift. De organisatoriske og pædagogiske udfordringer spiller således sammen med kompetenceudviklingen på det undervisningspraktiske K1-niveau og 
Tema: Innovation og uddannelse

på de videns- og erfaringsudvekslende K2- og K3-niveauer. Her vil InterTværs' sundhedsfaglige indhold og curriculum være interprofessionelt tonet, ikke som en addering af de respektive professionsuddannelsers curriculum eller kritisk drøftelse for konsistens, snarere som en argumentation, der primært hentes i 'gode fortællinger'. I InterTværs synes dette knyttet til et igangværende paradigmeskifte og til den fælles sag, som det vises i næste afsnit.

\section{Den fælles sag: Orienteret mod patient-/borgerforløbet}

Som uddannelsesprojekt betragtes InterTværs af de fire parter, som et bud på fremtidens velfærdsuddannelser og som et svar på omverdenens krav om et sammenhængende patient-/ borgerforløb. Her tager InterTværs del i det igangværende paradigmeskifte, der anskuer patient-/borger som aktiv og ligeværdig samarbejdspartner. Feltarbejdets foreløbige analyser bekræfter patient-/ borgerorienteringen, men viser også, at InterTværs på én og samme gang kan virke stimulerende og konserverende. InterTværs-teamet formulerer sammen med patienten fælles mål for forløbet, som vel at mærke er patientens mål. Dette stimulerer til en praktisk målsætning, der kontrasterer Gittells orientering mod organisation og ledelsesniveauet. Men om end InterTværs i sin konsekvente orientering mod uddannelsesniveauet og patient-/borger fokuseringen fungerede stimulerende, så viste praksis eksempler på, at InterTværs-team i lighed med traditionel praksis præsenterede patient-/borgeren for de professionelles vurdering og beslutninger, som fordrede patient/borgerens informerede samtykke. I videreførelse af sådanne traditioner virker InterTværs (om end mod hensigten) konserverende. Analyser på studenter- og supervisionsniveauet tyder på, at de stimulerende intentioner genoptages, idet der i senere InterTværsforløb ses udvikling af fælles mål, som er patientens mål - på trods af afdelingens manglende praksis herfor. Inddrages det institutionelle niveau, bliver det snarere som 'fravær' af drøftelser om patient/borgerens rolle i målformulering. Drøftelser, af paradigmeskiftet mod patient-/borgeren som samarbejdspartner, træder i baggrunden for fokus på planlægning, afvikling og evaluering af InterTværs-forløb. Drift og udvikling er i fokus på platformen. Trods driftsorientering repræsenterer underviser-praksisfællesskaberne fortsat forbindelsen til InterTværs-projektet rettet mod de fælles løsninger og mål. InterTværs-forløbet organiseres ikke horisontalt med de respektive professionsuddannelsers curriculum, men snarere ved at praksisfællesskaberne argumenterer med 'gode fortællinger' relateret til det igangværende paradigmeskifte. Men hermed risikerer praksisfællesskaberne blot at genforhandle spørgsmålet om uddannelsens orientering. Selve professions- og interprofessionsfagligheden berøres ikke. Udtrykt med inspiration fra Engeström risikerer praksisfællesskaberne, at dialogen og redskabsbrugen går i stå, og der ikke sker ekspansion (2012). At komme risici i møde og at skabe sammenhængende patient-/borgerforløb fordrer, at InterTværs-aktører indgår i kredsløb, hvor der produceres og anvendes ny viden rettet mod såvel interprofessionel fagudvikling som pædagogisk udvikling. Herved fordres det, der med Engeström betegnes som ekspansiv læring, udfordring fra andre virksomhedssystemer og af interne modsætninger (Engeström 2009).

\section{Afrunding}

Feltarbejdet og de foreløbige analyser peger på, hvordan InterTværsPlatformen på uddannelsesniveauet fungerer og stimulerer ekspansiv læring. Som indskudt platform mellem sundhedsvæsen og professionsuddannelser skabes viden- og erfaringsudveksling mellem nye underviser-praksisfællesskaber. På tværs af professioner relateres interprofessionelle studieforløb til patient/borgeren i reale forløb. Ved at forskyde orienteringen mod en patient-/ borgercentreret, interprofessionel, tværsektoriel orientering, fremstår InterTværs som et udviklingsprojekt, der i praktisk forstand skaber et interprofessionelt uddannelsesalternativ, samtidig med at alternativet udfordres og presses til håndtering af praktisk drift. Hermed peger artiklen på vilkårene for at skabe professionspædagogiske platforme i det erhvervs- og samfundsorienterede paradigme. Men artiklen peger også på nødvendigheden af at skabe platforme for professionslæring, der bibeholder nærheden til projekternes praksisfællesskaber og matcher uddannelsesniveauets relationelle koordineringer frem for policy-niveauets. 
Projekt InterTværs og interprofessionalitet som det innovative match

\section{REFERENCER}

Borgnakke, K. 2013. Etnografiske metoder i uddannelsesforskningen - mellem klassiske traditioner og senmoderne udfordringer. København: Institut for Medier, Erkendelse og Formidling. Det Humanistiske fakultet, Københavns Universitet.

Borgnakke, K. \& Nielsen, C.S. 2015. Etnografiske studier i interprofessionalitet og forandringer af klassiske koncepter. Tidsskrift for professionsstudier. Gjallerhorn, DK, (20), 48-60.

Borgnakke, K. 1996. Pædagogisk feltforskning og procesanalytisk metodologi: Procesanalytisk teori og metode. Akademisk Forlag. København.

CAIPE 2002, Centre for the Advancement of Interprofessional Education, http://caipe.org.uk/

Dale, E.L. 1991. Pedagogisk professionalitet. Om pedagogikkens identitet og anvendelse. Gyldendal Norsk Forlag.

Engeström, Y. 2009. Ekspansiv læring - på vej mod reformulering af den virksomhedsteoretiske tilgang. I: Illeris (Red). Læringsteorier seks aktuelle forståelser. Roskilde Universitetsforlag. 3. udg. 81-108.

Engeström, Y. 2012. Ekspansiv læring - på vej mod en nyformulering af den virksomhedsteoretiske tilgang. I: Illeris (Red.). 49 tekster om læring. Samfundslitteratur. S. 443-466.

Gittell, HJ. 2012. Effektivitet i sundhedsvæsenet - samarbejde, fleksibilitet og kvalitet. Munksgaard.

Hammersley, M. \& Atkinson, P., 2007. Ethnography: principles in practice. London: Routledge, 3. ed.

InterTværs. Projektrapport. 2013: Interprofessionelle, tværsektorielle studieforløb - En model. www.auh.dk/intertvars

InterTværs; Model. 2015. Interprofessionelle, tværsektorielle studieforløb, hvor patient-/ borgerforløbet er det bærende princip.
IPLS. Dansk Selskab for Interprofessionel Læring og Samarbejde i sundhedsvæsenet. (http://ipls.dk/wordpress/).

Lave, J. \& Wenger, E. 2004 (1991). Situeret Læring - og andre tekster. Hans Reitzels Forlag. København.

Marcus, G.E. 1995. Ethnography in/of the World System: The Emergence of Multi-Sited Ethnography. Annual Review of Anthropology, 24, pp. 95-117.

Wenger, E. 2004 (1998). Praksisfællesskaber. Læring, mening og identitet. Hans Reitzels Forlag. København.

\section{ENDNOTES}

1 InterTværs iværksættes 2012 som et samarbejde mellem Aarhus Universitetshospital, Aarhus Kommune, Aarhus Universitet og VIA Sundhed. Cathrine Sand Nielsens ph.d.-projekt følger InterTværs fra februar 2014, Tina Kramers fra marts 2015.

2 Jævnfør ph.d.-projektbeskrivelser 'Etnografiske studier i Innovative Læringskontekster: http://mef.ku.dk/forskning/ fokusomraaderogprojekter/innovativelaeringsprocesser/.

3 InterTværs er rapporteret fortløbende, se InterTværs Projektrapport 2013, InterTværs Model 2015. Implementering af studieforløbet forløber frem til 2017. 